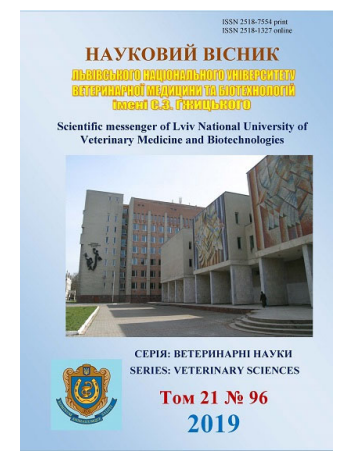

\author{
Науковий вісник Львівського національного університету \\ ветеринарної медицини та біотехнологій імені С.3. Гжицького. \\ Серія: Ветеринарні науки
}
Scientific Messenger of Lviv National University
of Veterinary Medicine and Biotechnologies.
Series: Veterinary sciences

UDC 618.617.637

\title{
Dynamics of cow mastitis disease in conditions of industrial milk production
}

\author{
A.O. Dovbnia, A.V. Berezovskiy, H.A. Fotina \\ Sumy National Agrarian University, Sumy, Ukraine
}

\section{Article info}

Received 05.11.2019

Received in revised form 10.12 .2019

Accepted 11.12.2019

Sumy National Agrarian University, Herasima

Kondratieva Str., 160

Sumy, 40000, Ukraine.

Tel.: +38-050-330-21-90

E-mail:bav13@meta.ua

\begin{abstract}
Dovbnia, A.O., Berezovskiy, A.V., \& Fotina, H.A. (2019). Dynamics of cow mastitis disease in conditions of industrial milk production. Scientific Messenger of Lviv National University of Veterinary Medicine and Biotechnologies. Series: Veterinary sciences, 21(96), 171-176. doi: $10.32718 /$ nvlvet 9630
\end{abstract}

The article provides data on monthly monitoring of breast pathologies for lactating cows during 2019. Observations were made on a herd of cows of Holstein breed, the cows were kept free during all season. Cows were kept $n$ premises with a workshop structure of industrial milk production. In this farm, milking of cows was carried out three times in milking rooms with the equipment of the company GEA Farm Technologies models "Yalinka" and "Parallel".

The following six issues were addressed during the monthly monitoring:

determination of the dynamics of indicators characterizing the reproductive status of cows;

- finding out the effect of seasonality on the number of average monthly cow disease for mastitis during the year;

- tracking the degree of disease of cows with mastitis by months after calving lactation;

- determination of the degree of disease of cows with mastitis, depending on the number of their lactation in the farm;

- manifestation of the average monthly number of cow disease for clinical and subclinical mastitis;

- tracking the frequency of each of the four proportion of udders of lactating cows.

The data obtained are summarized in the relevant tables and discussed in the results section of the research, on which the main conclusions are drawn:

- manifestation of breast pathologies in cows varied by season.

The highest was in winter - 14.37\%; slightly lower - in summer and autumn (respectively 12.16 and $10.32 \%)$; and the lowest (6.41\%) - in spring months;

- the highest percentage of udders pathologies of lactating cows was noted in the first, fourth and fifth months of lactation (14.9, 13.7 and $11.43 \%$, respectively);

- the highest percentage of mastitis was observed in young cows from the first to the third lactation (respectively 18.0; 26.4 and $20.7 \%$ );

- the clinical form of mastitis most often was observed in winter months (92.1\%). In spring, its percentage decreased (up to $72.2 \%$ ) and increased slightly in summer (up to $83.1 \%$ ), while in autumn there was a significant reduction of this pathology to $49.9 \%$;

- consideration of frequency of impression of each share of udder of cows, shows that the majority of pathologies (57.1\%) were found on the posterior lobes.

Key words: cows, lactation, calving, mastitis, udder, seasonality.

\section{Динаміка захворювання корів на мастит в умовах промислового виробництва молока}

\author{
А.О. Довбня, А.В. Березовський, Г.А. Фотіна \\ Сумський національний аграрний університет, м. Суми, Украӥна
}


У статті наведено дані помісячного моніторингу патологій молочної залози лактуючих корів впродовж 2019 року. Спостереження проведено на стаді корів голштинізованої породи, які весь сезон безприв 'язно перебували в приміщеннях з иеховою структурою промислового виробництва молока. В даному господарстві доӥння корів проводилося триразово в доӥльних залах на обладнанні компанії GEA Farm Technologies моделі “Ялинка” та "Паралель”.

В ході шзомісячного моніторингу розглядались такі шість питань:

- визначення динаміки показників, щуо характеризують репродуктивний стан корів;

- з'ясування впливу сезонності на кількість середньомісячних захворювань корів на мастит впродовж року;

- відслідковування ступеня захворювання корів на мастит за місяцями після їхньої отельної лактації;

- визначення ступеня захворювання корів на мастит залежно від номера їхньӧ лактації в господарстві;

- прояву середньомісячної кількості захворювань корів на клінічний та субклінічний мастит;

- відслідковування частоти ураження кожної з чотирьох доль вимені лактуючих корів.

Отримані дані наведено у відповідних таблицях та обговорено в розділі “Результати досліджень”, за якими зроблено основні висновки про те, щио:

- прояв патологій молочної залози у корів різнився за сезонами року. Найбільш високим від був зимою - 14,37\%; дещо нижчим влітку та восени (відповідно 12,16 та 10,32\%); і найнижчим (6,41\%) - у весняні місяці;

- найвищий відсоток патологій молочної залози лактуючих корів відзначали на перший, четвертий $i$ n'ятий місяці лактації (відповідно 14,9; 13,7 mа 11,43\%);

- максимальний відсоток маститу спостерігали у молодих корів з першої по третю лактації (відповідно 18,0; 26,4 та 20,7\%);

- клінічну форму маститу найчастіше спостерігали в зимові місяиі (92,1\%). Весною відсоток його знижувався (до $72,2 \%$ ) та дещчо зростав улітку (до 83,1\%), а восени відбувалося значне зменшення ичієї патологї до 49,9\%; ля.

- розгляд частоти ураження кожної долі вимені корів свідчить про те, щзо більшість патологій (57,1\%) виявляли на задніх до-

Ключові слова: корови, лактація, отели, мастит, вим'я, сезонність.

\section{Вступ}

За поточне десятиліття молочне скотарство в нашій країні стало розвиватись в основному за рахунок інтенсифікації виробничих процесів, в основі яких процес посиленого виробництва молока із застосуванням промислових технологій. Проте, за даними Держстатистики України станом на початок вересня 2019 року, загальна кількість корів усіх форм власності становила 1,9 млн, при цьому дійне промислове стадо нараховувало лише 448,5 тис. гол. Разом з цим, за повідомленням аналітиків Асоціації виробників молока, динаміка зменшення чисельності корів в державі 3 кожним місяцем посилюється, а найбільші темпи скорочення демонструє промислове поголів'я.

Відомо, що одною з головних причин передчасного вибуття корів $є$ захворювання репродуктивних органів та молочної залози корів (Stefanyk \& Shpak, 2012; Korol, 2013; Vakkamaki et al., 2017). Серед хвороб молочних корів особливе місце займає мастит запалення молочної залози, що розвивається внаслідок впливу механічних, термічних, хімічних і біологічних факторів. При цьому ця проблема характерна не лише для вітчизняного скотарства. Незважаючи на багаторічний досвід та розробку численних лікувальних схем, мастит $є$ найпоширенішим захворюванням молочного стада у багатьох країнах (Bogush et al., 2009; Dojtc \& Obritchauzer, 2010; Berezovskyi et al., 2010; Hulps et al., 2010).

Мета $і$ завдання дослідження. 3'ясувати динаміку захворювання корів на мастит в умовах промислового виробництва молока.

Для досягнення поставленої мети необхідно було вирішити п'ять таких завдань:

- провести аналіз прояву середньомісячної кількості захворювань корів на мастит за 2019 рік;

- встановити рівень захворювання корів на мастит за місяцями після їхньої отельної лактації;
- визначити рівень захворювання корів на мастит залежно від кількості лактацій в господарстві;

- визначити показники прояву середньомісячної кількості захворювань корів на клінічний та субклінічний мастит за рік;

- зіставити частоту ураження кожної з чотирьох доль вимені.

\section{Матеріал і методи досліджень}

Спостереження за станом молочної залози молочних корів провели продовж 2019 року в господарстві із промисловою технологією виробництва молока, що розташоване в степовій зоні Півдня України. Основу стада складають корови голштинізованої породи. Їх постійно утримують безприв'язно при цеховій структурі виробництва, де функціонують підрозділи: дійне стадо, ранній сухостій, пізній сухостій і родилка. Доїння проводиться триразово в доїльних залах на обладнанні компанії GEA Farm Technologies моделі “Ялинка" та "Паралель". Його розпочинають щоденно в такі години: перше - о 5:30 ранку, друге - о 13:30 дня та вечірнє - о 21:30. Запуск корів проводять переважно на 222-228-му добу тільності. Відбір проб для діагностики субклінічного маститу (каліфорнійський тест) проводиться щопонеділка під час вранішнього доїння.

\section{Результати та їх обговорення}

3 даних, що наведено в таблиці 1, видно, що показник середньомісячної кількості лактуючих корів в даному господарстві досить стабільний впродовж календарного року. Рівень його коливання від найвищого (квітень) до найнижчого (жовтень) не перевершував $15 \%$, що свідчить про належний стан організаційно-зоотехнічного забезпечення. Проте помітно варіюючий середньомісячний відсоток сухостійних корів (min $-8,75, \max -16,7 \%)$ може вказувати на 
періодичні проблеми із запліднювальною здатністю корів та нерівномірність процесу розтелень нетелів.

Виходячи з аналізу прояву захворювання корів на мастит за місяцями та сезонами року (табл. 2) варто відмітити стабільність в підтримці показника "кількість фуражних корів”. Разом $з$ цим належить зазначити, що поняття “вперше хворі” та “повторно хворі” стосуються не цілого життя корів, а лише поточного періоду цього (2019) року. На жаль, існуюча програма статистики хвороб у корів до категорії “повторно хворі" - зараховувала і тих тварин, які впродовж календарного року хворіли на мастит третій чи й четвертий раз.

\section{Таблиця 1}

Рівень і динаміка показників, що характеризують репродуктивний стан корів

\begin{tabular}{|c|c|c|c|c|c|c|c|c|c|c|c|c|}
\hline \multirow[b]{2}{*}{ Показники } & \multicolumn{12}{|c|}{ Місяці року } \\
\hline & 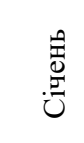 & 恣 & 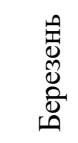 & 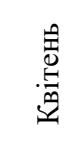 & 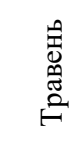 & 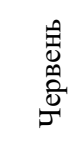 & 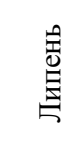 & 㐫 & 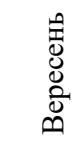 & 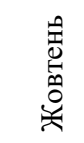 & 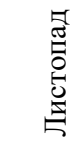 & 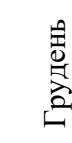 \\
\hline Кількість дійних корів & 1217 & 1262 & 1273 & 1282 & 1244 & 1205 & 1178 & 1181 & 1138 & 1089 & 1112 & 1164 \\
\hline $\begin{array}{l}\text { Кількість сухостійних } \\
\text { корів }\end{array}$ & 181 & 143 & 129 & 123 & 145 & 187 & 209 & 207 & 225 & 218 & 207 & 200 \\
\hline \% сухостійних & 12,9 & 10,2 & 9,2 & 8,75 & 10,4 & 13,4 & 15,0 & 14,9 & 16,5 & 16,7 & 15,7 & 14,7 \\
\hline \% тільних корів у стаді & 54 & 56 & 58 & 62 & 64 & 64 & 64 & 60 & 57 & 49 & 44 & 55 \\
\hline Отелилось корів (гол) & 105 & 83 & 63 & 58 & 44 & 53 & 87 & 85 & 95 & 104 & 99 & 87 \\
\hline $\begin{array}{l}\text { Отелилось нетелів } \\
\text { (гол) }\end{array}$ & 83 & 31 & 30 & 25 & 33 & 30 & 41 & 39 & 52 & 36 & 73 & 57 \\
\hline $\begin{array}{l}\text { \% отелень (нетелі) від } \\
\text { фуражних }\end{array}$ & 5,9 & 2,2 & 2,1 & 1,8 & 2,4 & 2,15 & 2,95 & 2,8 & 3,8 & 2,75 & 5,3 & 4,1 \\
\hline Сервіс період & 132 & 131 & 126 & 123 & 119 & 118 & 119 & 117 & 119 & 124 & 136 & 134 \\
\hline Між отельний період & 407 & 417 & 404 & 420 & 426 & 415 & 404 & 408 & 413 & 407 & 406 & 406 \\
\hline
\end{tabular}

Таблиця 2

Аналіз середньомісячної кількості захворювань корів на мастит за 2019 рік

\begin{tabular}{|c|c|c|c|c|c|c|c|c|c|c|c|c|}
\hline \multirow[b]{2}{*}{ Показники } & \multicolumn{12}{|c|}{ Місяці року } \\
\hline & 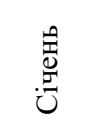 & $\begin{array}{l}\text { 罖 } \\
\text { 虽 }\end{array}$ & 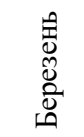 & 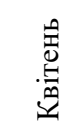 & 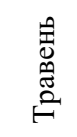 & $\begin{array}{l}\text { 总 } \\
\text { 苞 } \\
\stackrel{0}{0}\end{array}$ & 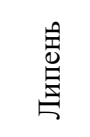 & 恋 & 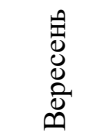 & 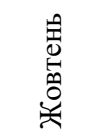 & 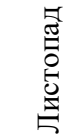 & $\begin{array}{l}\text { 竞 } \\
\text { 至 } \\
\text { 至 }\end{array}$ \\
\hline Фуражне поголів’я & 1398 & 1405 & 1402 & 1405 & 1389 & 1392 & 1387 & 1388 & 1363 & 1307 & 1319 & 1364 \\
\hline $\begin{array}{l}\text { Випадки маститу } \\
\text { вперше }\end{array}$ & 54 & 66 & 71 & 43 & 45 & 58 & 61 & 43 & 67 & 58 & 42 & 42 \\
\hline \% до поголів’я & 3,86 & 4,7 & 5,06 & 3,06 & 3,23 & 4,16 & 4,39 & 3,09 & 4,91 & 4,43 & 3,18 & 3,08 \\
\hline $\begin{array}{l}\text { Повторні випадки } \\
\text { маститу }\end{array}$ & 129 & 87 & 26 & 29 & 54 & 139 & 93 & 103 & 88 & 85 & 72 & 219 \\
\hline \% до поголів'я & 9,23 & 6,19 & 2,14 & 1,99 & 3,75 & 9,99 & 6,57 & 7,50 & 6,46 & 6,51 & 5,46 & 16,05 \\
\hline $\begin{array}{l}\text { Випадки маститу } \\
\text { вього }\end{array}$ & 183 & 153 & 101 & 71 & 97 & 197 & 152 & 147 & 155 & 143 & 114 & 261 \\
\hline \% до поголів'я & 13,09 & 10,89 & 7,2 & 5,05 & 6,98 & 14,15 & 10,96 & 10,59 & 11,37 & 10,94 & 8,64 & 19,13 \\
\hline $\begin{array}{l}\text { Добовий надій на } \\
\text { лактуючу корову (л) }\end{array}$ & 32,1 & 33,3 & 33,8 & 33,4 & 33,0 & 29,1 & 29,5 & 27,7 & 26,7 & 27,2 & 28,2 & 29,9 \\
\hline
\end{tabular}

Відсоток вперше хворих тварин упродовж року корелював 3 сезонністю. В зимовий період (січень, лютий + грудень) загальна кількість корів, хворих на мастит, склала 627 голів. Цей же показник за весняні місяці (березень-травень) становив лише 269 голів, що в 2,3 разу нижче за попередню зиму. Наступне суттєве середньомісячне зростання відсотка хворих спостерігалося в червні (до 14,15\%). Найбільш вірогідне пояснення цього: червень був найспекотнішим місяцем літа, більшість днів його денна температура була в межах $30-37^{\circ}$ C. А вже в останні два літніх місяці та три осінніх кількість “вперше хворих” була приблизно рівною (3,08-4,91\% від наявного фуражного поголів'я). Отримані показники сезонності маститів дещо нижчі, ніж раніше спостерігали білоруські науковці (Bogush et al., 2001), в яких вони варіювали в межах від 6,8 до 21,3\%.

Проте загалом, з урахуванням "повторно хворих", сумарний відсоток корів з патологією молочної залози суттєво різнився за сезонами року. Найвищим він був зимою - 14,37\%; дещо нижчим - влітку та в осінній періоди (відповідно 12,16 та 10,32\%) і найнижчим 
(6,41\%) - у весняні місяці. При цьому середньодобовий надій на лактуючу корову був досить високим впродовж всього року, що свідчить про хороше та рівномірне всесезонне забезпечення стада кормами. Але й на такому фоні за піврічний період (червеньлистопад) відбулось зниження добових надоїв порівняно з попереднім періодом майже на 15\%, яке корелювало з ростом патології молочної залози у стаді, що відповідно спостерігалося.

Із аналізу показників захворювання корів на мастит за місяцями після отельної лактації (табл. 3) вид- но, що найбільшу кількість патологій молочної залози лактуючих корів, окрім першого місяця лактації $(14,9 \%)$, ще відзначали на четвертий і п'ятий місяці лактації (відповідно13,7 та 11,4\%). Показник “відсоток маститу вперше” з першого по п'ятий місяць зростав - від 14,9 до 36,9\%. Водночас повторні захворювання на рівні понад 90\% щомісячно виявляли безперервно 3 шостого по одинадцятий місяць лактації включно. Найвищі рівні захворювання свіжоотелених корів в різний час відмічали й зарубіжні дослідники (Erskine et al., 2002; Blum et al., 2017).

\section{Таблиця 3}

Рівень захворювання корів на мастит за місяцями після їхньої отельної лактації

\begin{tabular}{|c|c|c|c|c|c|c|c|c|c|c|c|c|}
\hline \multirow{2}{*}{ Показники } & \multicolumn{12}{|c|}{ Місяці після отельної лактації корів } \\
\hline & 1 & 2 & 3 & 4 & 5 & 6 & 7 & 8 & 9 & 10 & 11 & $>11$ \\
\hline $\begin{array}{l}\text { Захворіли на } \\
\text { мастит всього }\end{array}$ & 266 & 107 & 120 & 244 & 203 & 97 & 85 & 109 & 108 & 106 & 98 & 231 \\
\hline $\begin{array}{l}\text { \% маститу } \\
\text { лактуючих }\end{array}$ & 14,9 & 6,0 & 6,8 & 13,7 & 11,4 & 5,3 & 4,4 & 6,5 & 6,3 & 5,9 & 5,5 & 13,0 \\
\hline Мастит вперше & 266 & 32 & 37 & 89 & 75 & 2 & 5 & 1 & 3 & 5 & 1 & 9,1 \\
\hline $\begin{array}{l}\text { \% маститу } \\
\text { вперше }\end{array}$ & 14,9 & 29,9 & 30,8 & 36,5 & 36,9 & 2,1 & 5,9 & 0,9 & 2,8 & 4,7 & 1,1 & 21 \\
\hline $\begin{array}{l}\text { Повторний } \\
\text { мастит (гол.) }\end{array}$ & 0 & 75 & 83 & 155 & 128 & 95 & 80 & 108 & 105 & 101 & 97 & 208 \\
\hline $\begin{array}{l}\text { \% повторного } \\
\text { маститу }\end{array}$ & 0 & 70,1 & 68,2 & 63,5 & 63,1 & 97,9 & 94,1 & 99,1 & 97,2 & 95,3 & 98,9 & 90,9 \\
\hline
\end{tabular}

В процесі порівняння показників захворювання корів залежно від кількості лактацій в даному господарстві впродовж поточного року спостережень 3'ясовано (табл. 4), що найчастіше мастит спостерігали у молодих корів перших трьох лактації (відповідно
18,$0 ; 26,4$ та 20,7\%). Водночас в категорії “\% маститу вперше" наростання проходило від корів-первісток $(25,6 \%)$ до третьої лактації (41,0\%). Від четвертої до восьмої лактації цей показник плавно знижувався.

\section{Таблиця 4}

Рівень захворювання корів на мастит залежно від номера їхньої лактації в господарстві

\begin{tabular}{lccccccc}
\hline \multicolumn{1}{c}{ Показники } & \multicolumn{7}{c}{ Номери лактації } \\
\cline { 2 - 8 } & 1 & 2 & 3 & 4 & 5 & 6 & $7+$ \\
\hline Захворіло на мастит всього & 320 & 469 & 368 & 264 & 235 & 83 & 35 \\
\% маститу лактуючих & 18,0 & 26,4 & 20,7 & 14,9 & 13,2 & 4,7 & 1,9 \\
Мастит вперше & 82 & 150 & 151 & 88 & 56 & 17 & 6 \\
\% маститу вперше & 25,6 & 32,0 & 41,0 & 33,3 & 23,8 & 20,5 & 17,2 \\
Повторний маститу & 238 & 319 & 217 & 176 & 179 & 66 & 29 \\
\% повторного маститу & 74,4 & 68,0 & 59,0 & 66,7 & 76,2 & 79,5 & 82,8 \\
\hline
\end{tabular}

Місячне співвідношення кількості клінічних та субклінічних виявлених маститів також мінялася залежно від сезону року (табл. 5). При цьому показник “\% клінічного маститу" найчастіше діагностували в зимові місяці (від 94,1 до 89,9\%). Його середній відсоток помітно знижувався весною (до 72,2\%), дещо зростав улітку - до 83,1\%. 3 настанням осені він дуже знижувався (до 49,9\%), а відповідно зростала (до 45,6-52,4 \%) частка субклінічних патологій. Це може свідчити про те, що менш тяжкий перебіг та зниження симптомів хвороби, пов'язано із підвищенням імунної резистентності у корів стада внаслідок кращої годівлі та погоди. Ця статистика також може підтверджувати досвідченість та ефективність роботи операторів машинного доїння, до обов'язків котрих належить виявлення корів із клінічним маститом.

При проведенні порівнянь частоти ураження кожної з чотирьох доль вимені (табл. 6) видно, що більшість патологій $(57,1 \%)$ припало на дві задні долі.

Частково це, напевне, можна пов'язати із їхнім можливим травматизмом під час лежання. Травми бувають заподіяні іншими тваринами, які всі є безприв'язними. Окремі евентуальні технічні неполадки доїльного обладнання, на думку ряду авторів, також в значній мірі можуть провокувати зародження маститу (Klimov et al., 2013; Tse et al., 2016; Barkova, 2018). 


\section{Таблищя 5}

Аналіз середньомісячної кількості захворювання корів на клінічний та субклінічний мастит за 2019 рік

\begin{tabular}{|c|c|c|c|c|c|c|c|c|c|c|c|c|}
\hline Показники & 袁 & 恣 & 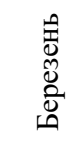 & 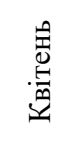 & $\begin{array}{l}\text { 总 } \\
\text { 惫 } \\
\text { 总 }\end{array}$ & $\begin{array}{l}\text { 总 } \\
\text { 峁 } \\
\text { 心 }\end{array}$ & $\begin{array}{l}\text { 恋 } \\
\text { 点 }\end{array}$ & $\begin{array}{l}\hat{E} \\
\text { 总 } \\
\text { 巳 }\end{array}$ & 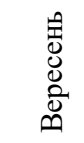 & $\begin{array}{l}\text { 焉 } \\
\stackrel{0}{0} \\
\stackrel{0}{0}\end{array}$ & 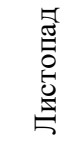 & 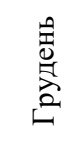 \\
\hline $\begin{array}{l}\text { Всього хворих на } \\
\text { мастит (гол) }\end{array}$ & 183 & 153 & 101 & 71 & 97 & 197 & 152 & 147 & 155 & 143 & 114 & 261 \\
\hline $\begin{array}{l}\text { Клінічний } \\
\text { мастит (гол.) } \\
\text { Клінічний }\end{array}$ & 171 & 136 & 83 & 47 & 71 & 185 & 121 & 111 & 74 & 68 & 62 & 246 \\
\hline $\begin{array}{l}\text { мастит до хворих } \\
(\%)\end{array}$ & 93,4 & 88,9 & 82,1 & 60,9 & 73,6 & 93,9 & 79,8 & 75,7 & 47,6 & 47,6 & 54,4 & 94,1 \\
\hline $\begin{array}{l}\text { Субклінічний } \\
\text { мастит (гол.) }\end{array}$ & 12 & 17 & 18 & 24 & 16 & 12 & 31 & 38 & 81 & 75 & 52 & 15 \\
\hline Субклінічний & & & & & & & & & & & & \\
\hline $\begin{array}{l}\text { мастит до хворих } \\
(\%)\end{array}$ & 6,6 & 11,1 & 7,9 & 39,1 & 26,4 & 6,1 & 20,2 & 24,3 & 52,4 & 52,4 & 45,6 & 5,9 \\
\hline
\end{tabular}

Таблиця 6

Аналіз порівнянь частоти ураження кожної з чотирьох доль вимені

\begin{tabular}{cccccc}
\hline Передня ліва & Передня права & \multicolumn{2}{c}{ Сумарно дві передні } \\
\hline Випадки & 406 & Випадки & 355 & Випадки & Сумарно дві задні \\
\hline Задня ліва & Задня права & \multicolumn{2}{c}{ Вугі } \\
\hline Випадки всього & 543 & Випадки всього & 470 & Випадки всього & 1013 \\
\hline
\end{tabular}

Проте інші автори схильні до думки, що вищий відсоток ураження клінічно вираженим маститом задніх чвертей пов'язаний з підвищеною, порівняно 3 передніми чвертями, продуктивністю, а отже і чутливістю до несприятливих факторів зовнішнього середовища (Baidevliatov \& Baidevliatova, 2019).

\section{Висновки}

1. Сумарний відсоток корів з патологією молочної залози суттєво різнився за сезонами року. Найвищим від був зимою - 14,37\%; дещо нижчим - влітку та в осінній періоди (відповідно 12,16 та 10,32\%) і найнижчим $(6,41 \%)$ - у весняні місяці.

2. Найвищий відсоток патологій молочної залози лактуючих корів, окрім першого місяця лактації $(14,9 \%)$, ще відзначали на четвертий і п'ятий місяці лактації (відповідно 13,7 та 11,4\%). Показник “\% маститу вперше" системно зростав 3 першого по п'ятий місяць - від 14,9 до 36,9\%. Водночас повторні захворювання на рівні понад 90\% виявляли безперервно 3 шостого по одинадцятий місяць після родової лактації включно.

3. Щодо загальної кількості хворих, максимальний відсоток маститу спостерігали у молодих корів 3 першої по третю лактації (відповідно 18,0; 26,4 та 20,7\%). При цьому у категорії “\% маститу вперше” наростання даного показника проходило від корів-первісток (25,6\%) до корів третьої лактації (41,0\%). Від четвертої до восьмої лактації цей показник плавно знижувався.

4. Клінічну форму маститу найчастіше діагностували в зимові місяці $(92,1 \%)$. Його відсоток помітно знижувався весною (до 72,2\%) та дещо знову зростав улітку (до 83,1\%). 3 настанням осені відбувався значне зменшення цієї форми патології (до 49,9\%), а відповідно зростала (до 45,6-52,4\%) частка субклінічних відхилень.

5. Аналіз порівнянь частоти уражень кожної долі вимені свідчить, що більшість цих патологій $(57,1 \%)$ припало на дві його задні долі.

Перспектива подальших досліджень. Визначити види збудників при різних формах маститу та встановити їхню чутливість до складових антимаститних засобів.

Baidevliatov, Yu.A., \& Baidevliatova, Yu.V. (2019). Poshyrennia mastytu ta osoblyvosti urazhennia chvertei molochnoi zalozy u koriv riznykh porid $\mathrm{u}$ hospodarstvakh Sumskoi oblasti. Visnyk Poltavskoi derzhavnoi ahrarnoi akademii, 2, 227231. doi: 10.31210/visnyk2019.02.30.

Barkova, A.S. (2018). Vlijanie sovremennyh tehnologij mashinnogo doenija na sostojanie molochnoj zhelezy korov. Veterinarija, 6, 41-45 (in Russian).

Berezovskyi, A.V., Fotina, T.I., \& Khomutov, S.L. (2010). Metodychni rekomendatsii shchodo alternatyvnykh metodiv korektsii ta zapobihannia mastytu u koriv. Kyiv (in Ukrainian).

Blum, S.E., Heller, E.D., Jacoby, S., Krifucks, O., \& Leitner, G. (2017). Comparison of theimmuneres ponsesasso ciatedwithex perimental bovine mastitis causedby differents trainsof Escherichia coli. Journal of Dairy Research, 84(2), 190-197. doi: $10.1017 / \mathrm{S} 0022029917000206$. 
Bogush, A.A., Ivanov, V. I., \& Borodija, L.V. (2009). Mastit korov i mery ego profilaktiki. Minsk: Belprint (in Russian).

Bogush, A.A., Ivanov, V.I., \& Golynec, V.G. (2001). Zabolevaemost' korov mastitami na zhivotnovodcheskih fermah. Veterinarnaja medicina Belarusi, 1, 4142 (in Russian).

Dojtc, A.V., \& Obritchauzer, V. (2010). Zdorov'e vymeni i kachestvo moloka: Prakticheskoe posobie. Per. s nemeckogo. Kiev: Artur Medien Ukraina (in Russian).

Erskine, R.J., Bartlett, P.C., VanLente, J.L., \& Phipps, C.R. (2002). Efficacy ofS ystemic Ceftiofuras a Therapy for Severe Clinical Mastitis in Daily Cattle. Journal of Dairy Science, 85(10), 2571-2575. doi: $10.3168 /$ jds.S0022-0302(02)74340-3.

Hulps, K., Lam, T.J., \& Hogeveen, H. (2010). Costs of mastitis: facts and perception. S. DairyRes, 75(1), 113-120. doi: 10.1017/S0022029907002932.

Klimov, N.T., Mihaljov, V.I., Nezhdanov, A.G., \& Pershin, S.S. (2013). Tehnologicheskie parametry mashinnogo doenija i zabolevaemost' korov mastitami. Veterinarija, 8, 37-39 (in Russian).
Korol, S.A. (2013). Osnovni zakhvoriuvannia VRKh na molochnykh fermakh Ukrainy. Ch. 2. Profilaktyka mastytu koriv. Suchasna veterynarna medytsyna, (6), 56-58 (in Ukrainian).

Stefanyk, V.Yu., \& Shpak, M.O. (2012). Mastyt u neteliv i koriv-pervistok. Naukovyi visnyk Lvivskoho natsional-noho universytetu veterynarnoi medytsyny ta biotekhnolohii im. Gzhytskoho, 14, 2(1), 318-329. Rezhym dostupu: http://nbuv.gov.ua/UJRN/ nvlnu $2012 \quad 14 \quad 2 \% 281 \% 29 \quad 61$ (in Ukrainian).

Tse, C., Barkema, H.W., De Vries, T.J., Rushn, J., \& Paer, E.A. (2016). Effect of transitioning to automatic milking systems on producers perceptions of farm management and cow health in the Canadian dairy industry. Journal of Dairy Science, 100(3), 2404-2414. doi: 10.3168/jds.2016-11521. https://www.ncbi.nlm. nih.gov/pubmed/28109587.

Vakkamaki, J., Taponen, S., Heikkila, A.M., \& Pyorala, S. (2017). Bacteriological etiology and treatment of mastitis in Finnish dairy herds. Acta Veterinaria Scandinavica, 59(1), 33. doi: 10.1186/s13028-017-0301-4. 